\title{
The Evaluation of the Effectiveness of Counterterrorism Policies on the PKK-inflicted Violence during the Democratization Process of Turkey
}

\section{by Irfan Ciftci and Sedat Kula}

\section{(cc) $\mathrm{BY}$}

This work is licensed under a Creative Commons Attribution 3.0 License.

\begin{abstract}
This study tries to explore the relationship between soft-line governmental policy interventions of Turkey and the responses of the PKK (The Kurdistan Workers' Party) by using time series data from 1995 to 2010. The negative binomial specifications for two models, the number of incidents and the number casualties are used. The aggregated impact of soft-line policies on the level of violence is found to be positive and significant. In one hand, Turkey's EU accession process had a decreasing impact on PKK inflicted violence. On the other hand, the Active Repentance Law increased the violence in the short run. It was found that defiance based governmental policy interventions of Turkey had an increasing impact on the PKK-inflicted violence.
\end{abstract}

Keywords: Kurdish Conflict, The PKK, Counter-terrorism, Violence, Soft-line policies

\section{Introduction}

errorism is one of the most complex social phenomena in the age of globalization and the September 11 is considered a turning point in the development of counter-terrorism policies throughout the world. Terrorism is defined by The United States Department of Defense as "the calculated use of unlawful violence or threat of unlawful violence to inculcate fear; intended to coerce or to intimidate governments or societies in the pursuit of goals that are generally political, religious, or ideological." (http://www. terrorism-research.com).

Separatist terrorism, originate from ethnic conflicts, is one of frequently witnessed terrorist events across the world. The unanticipated increase in the number ethnic terrorist events during the post-cold war period has taken scholars' attention (C.P. Barros, Passos, and Gil-Alana 2006; Carlos Pestana Barros 2003; Enders and Sandler 2000; Kim and Yun 2008; Steinberg 2008; Teymur and Smith 2008; Ünal, 2009) to evaluate the factors behind ethnic conflict. The question of to what extent counterterrorism policies are effective is also tried to be investigated.

The studies on terrorism ( i.e., Crenshaw 1999; Eser 2007; Mead 2005; Netanyahu 1995; Ünal 2011; Wilkinson 2011) revealed different policies and intervention strategies used by countries to deal with terrorism. Intervention strategies vary from country to country due to the social, economic, and internal factors, some have hard-line characteristics and some have soft-line.

In terms of Turkey's last 30 years domestic and foreign political agenda, the Kurdish case (some claim problem) undoubtedly is a significant problem that Turkey faces. The major aim of PKK (Kurdistan Worker's Party) is to hinder the integration of the Southeast Anatolia region to the rest of the country. Since 1984, 


\section{Journal of Terrorism Research}

this violent conflict between two sides results in more than 30,000 death and over 300 billion dollars has been spent to end the problem (Feridun and Shahbaz 2010). This problem not only has negative impact on Turkey's status as a rising regional power, but has also traversed its efforts in the joint process to EU (Birch 2009; Ünal 2011).

Deterrence-based policies, including military actions, severe sanctions and punishments, emergency declaration for specific period of times, and forcing civilians to expel from their living places (Hewitt 1984; Netanyahu 1995), are the most common types of policies that states employ. The fact that many governments' policies, rather than addressing the root causes behind ethnic conflicts occurred in their countries, rely on strict military measures against ethnicity based terrorist groups is not rare (Feridun and Shahbaz 2010).

The application of only deterrence-based policies (Military Sanctions) is not found to be efficient solution to deal with ethnic terrorism. The most important step in the name of solving ethnic-based terrorism is to create policies and interventions that target to eliminate the underlying causes of ethnic conflict (Byman 1998). Findings of many researches (i.e., Lijpart 2004; Vorrath \& Krebs 2009; Windsor 2003) in the field revealed that democratic improvements have great importance to find long term solutions to solve ethnic conflicts and to prevent public support for terrorist groups.

In this sense, Turkey has tried to put the social and democratic projects into effect in order to meet the democratic demands of various ethnic groups with the aim of decreasing tensions that exist between ethnic groups in an ethnically divided society (Byman 1998). Prime examples of these initiatives can be seen during the early 2000 .

After 2001, Turkey began to enact democratic reforms to meet the EU demands and to stimulate its membership negotiations with the EU. This democratization process also brought about a change in the Turkish state's counterterrorism policies. Thanks to the driving force of the EU, Turkey issued nine democratic reform packages, which led to serious constitutional changes and challenged the basic principles of the Republican regime (Ulusoy, 2010). When we look at the details of these reform packages, we can see that there are several regulations that were intended to eliminate the Kurdish conflict such as the legalizing of the Kurdish language in public, allowing official and private Kurdish TV and radio broadcasting, Kurdish language courses, and releasing from prison four former deputies of the pro-Kurdish Democracy Party (DEP), including Leyla Zana (Dagi, 2006).

At the end of the 2009, the Erdogan government declared that they had launched the initiative popularly known as the "Democratic Opening". However, the democratic opening was later labeled the "Kurdish Opening". According to Ulusoy (2010), this can be explained by two situations arising from interlinked domestic and international factors; first, the AKP`s new strategy, which involved incorporating the Kurds by focusing their religious roots and offering them economic carrots, and the normalization of the political and economic situation in the southeast that increased the expectation for solving the Kurdish Issue. Admittedly, this process would require the government's response to Kurdish demands concerning cultural rights, freedom of expression, and governance. Second, international conjecture provided a great opportunity for the AKP to initiate such a difficult process of political transformation. The EU' fully supported this democratic initiative, and the positive international environment and the US' declaration of a withdrawal from Iraq created an opportunity for the government to solve the Kurdish Question. According to Barkey, the "Kurdish Opening" is a very serious effort by the government in terms of showing its changing mentality on the Kurdish Issue, whether or not it will succeed. He points out that this effort is also the most coherent and comprehensive attempt ever made in Turkey (Barkey, 2009). 


\section{Journal of Terrorism Research}

This study tries to explore the relationship between soft-line governmental policy interventions of Turkey and the responses of the PKK (The Kurdistan Workers' Party) in Turkey. For the purpose of the study, the time period between 1995 and 2010 are analyzed. The question of what the impact of such governmental policies on the extent of terrorist groups ' attacks during the democratization period in Turkey is tried to be answered.

\section{The Historical Background of the Kurdish Conflict}

The Turkish and Kurdish people have been living together for centuries. Both were considered members of the same social community under the Ottoman rule. Since the establishment of the Republic of Turkey, they have kept their status as equal citizens of the state. However despite this shared history, since the 19th century Turkey has faced contentious relationships between the Turks and Kurds, which has given rise to a protracted social conflict, called the "Kurdish Conflict" or "Kurdish Issue".[1]

During the Ottoman Empire in the $15^{\text {th }}$ and $16^{\text {th }}$ centuries, the Ottoman sultans had provided significant autonomy to local Kurdish leaders who demonstrated loyalty to the state (Ergil 2000). This structural situation in the Ottoman Empire did not create tension until the late 19th century, when the concept of "nationalism" arose in the world arena.

At the beginning of the creation of the new republic, Ataturk and other founder elites aimed to unite different ethnic minorities under a common Turkish identity (Kirişçi and Winrow 1997). After the establishment of the new Republic to create a modern and secular state that refused to follow the dynastic and religious affiliations of the Ottoman state structure (Ergil 2000b), a strong emphasis on "secular" values created tension among the Kurds, simply because of their cultural characteristics (Laciner \& Bal 2004).

Several Kurds rebellions against the Turkish state were seen from the foundation of Turkey until the death of Ataturk in 1938 (Hannum 1996, 185-186). The most important rebellion at this period was that of Sheikh Said. After his capturing a large part of the eastern Anatolian territory, the rebellion was suppressed by army forces sent by Turkish Government. Rebellion Sheikh Said resulted in execution of him and his army leaders (Entessar 2009).

Ergil (2000b) emphasizes two main reasons behind the development of the Kurdish uprisings after 1930s; first was the legal system of state that disregarded rule of law, social justice, and pluralism, and second reason was the initiatives to deport of Kurdish group from their ancestral lands due to every conflict occurred. After the 1980 military coup, the military administration (1980-1983) again banned the Kurdish language and changed the names of Kurdish towns and villages into Turkish names. Beside this, Kurdish families were forced to give Turkish names to their children.

\section{The Emergence of the PKK}

In 1973, the National Liberation Army was established by Abdullah Ocalan and his friends who were students in the Political Science Faculty at Ankara University (Cakar, Cengiz, and Tombul 2011) with the aim of creating an independent Kurdish state in the Anatolia region (Button 1995). With the help of NLA, Abdullah Ocalan got opportunity to consolidate his leadership skill and social network. Therefore, it would be easy to say that NLA was the first step that would take Abdullah Ocalan and his friends to formulate a separatist organization under the name of PKK. In 1978, the PKK was formally established with a notion of Marxist ideology by Abdullah Ocalan as a separatist terrorist organization with 23 of his friends, including some Turks, in Diyarbakir (Kutschera 1999). 


\section{Journal of Terrorism Research}

From the establishment until now, the PKK has organized eight congresses. In the second congress which was held in Damascus, Syria, in 1982, the PKK decided to begin a violent armed movement against the Turkish state to create an independent Kurdish state (Cakar, Cengiz, and Tombul 2011).

Killing more than a dozen people in 1984 was the first terror attack by the PKK. Even though Turkish army and police seemed to be the main target of the PKK, PKK killed many unarmed civilians in city centers. Interestingly, the majority of these killings were Kurdish civilians. Official records indicate that besides the police and army casualties, 5687 civilians were killed and 4274 civilians were wounded as a result of PKK's attacks between 1984 and 2009 (Ankara Papers 2004).

Kidnapping, assassination, bombing cars, suicide bombing, armed assaults, and attacking civilians and officials including teachers, health officers, police and military forces have been used by the PKK as attack strategies (Roth and Sever 2007).

Ocalan, the PKK leader, was captured by the Turkish Special Forces on February 16, 1999 in Nairobi, Kenya (Cornell 2011; Eser 2007; Sahin 2001). His capture is one of the most important milestones in Turkey's ongoing fight against the PKK. The PKK declared a unilateral and permanent ceasefire after Ocalan's capture within the frame of his manipulation to PKK militants seeking a peaceful solution of the Kurdish Problem. This unilateral and permanent ceasefire, the longest ceasefire which lasted almost 5 years by the PKK in its history, ended with PKK violence in 2004.

\section{Turkey's Counter-Terrorism Policies towards the PKK}

After the 1970s, more than hundred terrorist organizations were created in Turkey. Some are left and some are right oriented terrorist organizations. The DHKPC, MLKP, TKP, Turkish Hezbollah, Al-Qaida, TIT, and the PKK are the ones whose activities were predominantly seen (Eser 2007). Turkish State has great amount of experience dealing with these terrorist organizations. Turkey had success to terminate some of these organizations, but failed to deal with PKK case due to the some counterterrorism policies initiated by Turkish Governments and the national and international support given to PKK. Turkey`s response to the PKK terrorism has consisted largely of military measures, rather than other social-economic and reconciliation policies (Ünal 2011).

Turkey`s 30-years counterterrorism experience has clearly shown that the military options used to solve the PKK problem do not work on their own. 2001 Turkey's democratic reforms enacted in terms of membership negotiations with the EU have changed Turkey's counterterrorism policies. Besides the military measures against the PKK, indirect negotiations with Abdullah Ocalan were initiated in the name of solving problem (Çandar 2011). However, no reconciliation has yet been reached because of his unacceptable demands.

\section{Governmental Policies towards Ethnicity Based Terrorism}

\section{Deterrence (Hardline / Repressive) Based Approach}

The premise underlying deterrence based policies is best explained within the principles of rational choice theory. The basic idea behind rational choice theory is that of utility principle which argues that individuals strive to accomplish their own self-interests (Cauley and Im 1988; Dugan, Lafree, and Piquero 2005; Enders and Sandler 1993; Ünal 2011). From the terrorism point of view, members of terrorist organizations make a cost benefit analysis and consider the probability of success before they attempt to attack civilians or a state 


\section{Journal of Terrorism Research}

(Enders and Sandler 1993; Ünal 2011). Therefore, as deterrence based policy, governments are expected either to raise the cost or reduce the benefits of engaging terrorism activities.

This policy approach commonly includes "raising the certainty and severity of the punishment and apprehension by imposing heavier sanctions, increasing logistical complexity for terrorist attacks by tightening security measures in the potential targets, increasing threat of injury and death by conducting military operations" (Ünal 2009, 54-55).

In the PKK case, deterrence based policies including establishing collective punishment, eliminating leadership cadres, putting pressure on terrorism supporting countries, incapacitating terrorists, disintegrating the terrorist group and proclaiming a state of emergency are used as intervention policies by Turkish Governments for a long period of time (Ünal 2011). Even though studies on the effectiveness of hardline policies have produced inconstant results (i.e., Cauley \& Im 1988; Dugan et al. 2005; Enders \& Sandler 1993, 2000; Eser 2007; Hewitt 1984; Landes 1978; Ünal 2011), Mead (2005) emphasizes that deterrence based policies are the only way to prevent violent incidents both short and long run.

\section{Defiance Based Approach}

The basic premise of the Defiance theory (also known as Legitimacy Theory or soft-line approach) is that if policy interventions carried out by governments towards terrorists or their sympathizers are perceived as legitimate and fair by them in ethnically divided society, they are more likely to be effective in reducing violent incidents, especially in a long run (Lum, Kennedy, and Sherley 2006; Sherman 1993; Ünal 2011). Another argument raised by the advocates of defiance based policies (Crenshaw 1995; Wilkinson 2011) is that hardline counterterrorism policies to combat ethnicity based terrorism have a potential to create of mythologies of martyrdom, to strength group solidarity, and to increase public support for the militants. For the defiance theory, public opinion is the key factor in counterterrorism initiatives because one of the important goals of terrorists groups is to take public support and to be recognized by moderate societal members for their ideological or political goals (Crenshaw 1999; Kim and Yun 2008; Ünal 2011).

In the context of defiance and desistance based governmental policies to eliminate public support for terrorists/militants, democratic, social, and political reforms initiated by governments play vital role. Byman (1998) considers the implementation of democratic reforms or policies as crucial component of defiance based policies for promoting psychological disintegration between militants and sympathizers.

\section{Methodology and Data}

Time series analysis was conducted to measure the impacts of defiance and desistance based governmental policies on terrorist activities. Negative Binomial Model Estimation analysis was used in order to estimate the parameters of the model to be used in this study.

Research question of this study is as follows;

What is the impact of defiance-based governmental policies on PKK's activities during the democratization process of Turkey?

The year 1999 was selected as the turning point in terms of Turkish democracy in this study. Considering the democratization process of Turkey after 1995, four important defiance based policies were selected for this research: 


\section{Journal of Terrorism Research}

\section{D1: The Recognition of the Candidate Status of Turkey for Accession into the European Union (EU)}

Turkey`s candidate status for full membership was officially recognized by the EU on December 12, 1999, at the Helsinki summit (Keyman 2007). Even though Turkey`s journey was not a new phenomenon, because Turkey's official application to be a member of the EU was enacted on 14 April 1987, recognizing the application status of Turkey in 1999 has been accepted as a turning point for purposes of its democratic improvement (Balci 2008; Çarkoğlu and Rubin 2003; Keyman 2007). This is because Turkey initiated nine crucial democratic reforms in order to meet the EU demands at this time. In other words, Turkey`s membership to the EU meant improving its stand on human rights, minority rights, social welfare, religious rights, and democratic rights for its citizens, including Kurds, Turks, the Laz, Arabians, Circassians, Greeks and Armenians. Even though the accession process of Turkey into the EU not directly targeted terrorists, it was expected that the reform packages would prevent nationalist Kurds' support to the PKK by meeting the Kurdish people's demands. The democratic reforms were also assumed to result in reducing the PKK initiated violence since they were designed to decrease the political tensions among the Kurds.

\section{D2: The Returning Home Bill (July 2003- Jan 2004)}

In order to provide opportunities for the PKK militants to lay down their arms, the Turkish government initiated a number of repentance laws. Within the democratization context, one of the important repentance laws was "The Returning Home Bill” implemented between the years 2003 and 2004 when the unilateral ceasefire by the PKK was in force. This policy was based on encouraging the social integration process and providing amnesty for terrorists who wanted to capitulate by escaping from the PKK and it was implemented for six months during this period.

The Returning Home Bill was expected to result in reducing the PKK initiated violent incidents because it directly targeted terrorists and it was believed it would cause disintegration within the PKK.

\section{D3: The Active Repentance Law (Jun 2005 and after)}

The Active Repentance Law was implemented by the Turkish government with the same purpose and scope of the policy of the Returning Home Bill. It was initiated in 2005 and is still in effect. As seen in the Returning Home Bill policy, this intervention includes an amnesty and a reduction in punishment for the terrorists. This policy is still in force. When this policy began, sharp increase on the level of violence by means of incidents and causalities initiated by the PKK was observed in 2005. Then, this trend showed a sharp decrease until 2006.

\section{D4: The Democratic Initiative ("the Kurdish Opening") (Jul 2009 and after)}

At the end of 2009, The Turkish government put into effect the 'Democratic Initiative' popularly known as 'the Kurdish Opening' or 'the Democratic Opening. This initiative was based on efforts to respond effectively to Kurdish demands concerning cultural rights, freedom of expression, and governance. The Kurdish opening initiative is one of the most crucial policy initiatives in the history of the Kurdish conflict in terms of showing the Turkish State`s changing mentality regarding the Kurdish Issue (Barkey 2009). A prime examples of democratic reforms implemented the Turkish government are allowing free speech and singing in the Kurdish language in public, the opening of private Kurdish language courses, and the allowance of TV and radio broadcasting in Kurdish. According to Barkey, the "Kurdish Opening" is the most coherent and 


\section{Journal of Terrorism Research}

comprehensive attempt ever made in Turkey (Barkey 2009).

The Turkish government expectations has two fold; First, it was expected to reduce the PKK initiated violent incidents in a long run since the Turkish government had met some of the democratic demands of the Kurds. In other words, preventing public support for the terrorists was expected to result in a reduction of violent PKK incidents (Ünal 2011). Second, in the short run, this policy was expected to diminish existing tensions among the Kurds against the Turkish state, and reduce the Kurds`support for the terrorists.

The common point of these interventions is that these are defiance-based policies implemented by the Turkish Government to solve the existing problem to some extent.

Since selected policies are grievance-oriented, their purpose is to diminish these grievances by meeting certain demands concerning the Kurdish conflicts. Therefore, these interventions directly target the Kurdish people and sympathizers of the terrorist organization of the PKK, not the terrorists. These policies aim to reduce public support for the terrorists, which is the most crucial point in the fight against ethnicity based terrorist organizations. In this regard, these defiance-based policies are expected to result in reduced levels of violent attacks initiated by the PKK.

In contrast to these assumptions, some scholars argue that the transition period increases ethnicity-based terrorist attacks since it provides an opportunity for intensifying ethnic grievances in the short run. Terrorist group try to obstruct the democratic reforms initiated during transition periods. These democratic reforms might be perceived as sign of weakness by the terrorist organizations (Rustow 1970; Hewitt 1984; Horowitz 1985; Wilkinson 2011). Democratic initiatives have clearly shown that the PKK benefits from the deadlocks of the Kurdish question, and abuses the Kurds' demands for its political aims, but it does not want to lose its power in the region including Syria, Iran, and Iraq. Given these considerations, following hypotheses were formulated.

H1: The defiance-based policies implemented by Turkey would increase the number of incidents inflicted by the PKK during the democratization period in Turkey.

H2: The defiance-based policies implemented by Turkey would increase the number of casualties inflicted by the PKK during the democratization period in Turkey.

The Dataset was mainly drawn from the Global Terrorism Database (GTD), which is run by the University of Maryland. The GTD is an open-source database including information on terrorist events around the world from 1970 through 2010.

All recorded violent terrorist events (incidents and casualties) committed by the PKK between January 1 , 1995 and December 31, 2010 were used.

In addition to the GTD resources, unemployment rate, the number of police operations against PKK, the number of surrenders, the number of terrorists captured by the security forces, the long term ceasefire of PKK, and the capture of PKK leader were used as control variables for this study. These control data mainly collected from police units and statistical offices by visiting the Main HQ of those institutions.

The unemployment rate refers to the percentage of people who were unemployed and looking for a job at the national level during the selected time period of the study. The number of operations refers to the frequency of operations carried by security forces towards the PKK during the considered time period. Another control variable, the number of captured terrorist is the number of terrorists captured by the security forces in Turkey during the time period selected for this study. The number of surrenders refers to the total number of terrorists who were voluntarily capitulated from the PKK over the time period of the study. Control variable 


\section{Journal of Terrorism Research}

of group size is the yearly aggregated number of estimated group sizes of the PKK in Turkey, Iraq, Syria and Iran during the selected time period.

The Capture of the PKK Leader, Abdullah Ocalan is also selected as control variable since the capture of the PKK's leader, Abdullah Ocalan was one of the most important milestones in Turkey's ongoing fight against the PKK. The impact of seasonality was also taken into account, since it affects the numbers of casualties caused by the PKK, considering the weather and geographic conditions of Turkey. The number of casualties reached its maximum value during the summer seasons (Jul-Aug-Sept), a sharp decline was observed in the winter seasons.

The following table (Table 1) illustrates the characteristics of the study variables.

Table 1: Variables of the Study

\begin{tabular}{|c|c|c|c|c|c|}
\hline Variable & \multicolumn{2}{|c|}{ Description } & Source & Design & Code \\
\hline Frequency of incidents (INC) & DV & Count & GTD Database & $\begin{array}{l}\text { Aggregated number of violent inci- } \\
\text { dents by the PKK for each month }\end{array}$ & $Y_{1, \mathrm{~T}}$ \\
\hline $\begin{array}{l}\text { Frequency of casualties (CASU- } \\
\mathrm{AL} \text { ) }\end{array}$ & DV & Count & GTD Database & $\begin{array}{l}\text { Aggregated number of violent in- } \\
\text { cidents by the PKK for each month } \\
\text { that results in at least } 1 \text { casualty }\end{array}$ & $\mathrm{Y}_{2, \mathrm{~T}}$ \\
\hline $\begin{array}{l}\text { The recognizing of candidate } \\
\text { status of Turkey for membership } \\
\text { to the EU (D 1) }\end{array}$ & IV & Binary & Literature & $\begin{array}{l}0<\text { December } 1999 \\
1 \geq \text { December } 1999\end{array}$ & $\mathrm{D}_{1, \mathrm{~T}}$ \\
\hline The Returning Home Bill (D 2) & IV & Binary & Literature & $\begin{array}{l}0<\text { August 2003, } 1 \text { between Aug. } \\
2003 \text { and Jan. 2004. And 0>Jan. } \\
2004\end{array}$ & $\mathrm{D}_{2, \mathrm{~T}}$ \\
\hline $\begin{array}{l}\text { The Active Repentance Law (D } \\
\text { 3) }\end{array}$ & IV & Binary & Literature & $\begin{array}{l}0<\text { Jun } 2005 \\
1 \geq \text { Jun } 2005\end{array}$ & $\mathrm{D}_{3, \mathrm{~T}}$ \\
\hline $\begin{array}{l}\text { The Democratic Initiative ("the } \\
\text { Kurdish Opening") (D 4) }\end{array}$ & IV & Binary & Literature & $\begin{array}{l}0<\text { July } 2009 \\
1 \geq \text { July } 2009\end{array}$ & $\mathrm{D}_{4, \mathrm{~T}}$ \\
\hline $\begin{array}{l}\text { The Capture of the PKK leader } \\
\text { (ACTION) }\end{array}$ & $\mathrm{CV}$ & Binary & Literature & $\begin{array}{l}0<\text { February } 1999 \\
1 \geq \text { February } 1999\end{array}$ & $\mathrm{C}_{1, \mathrm{~T}}$ \\
\hline Unemployment Rate (UNEMP) & $\mathrm{CV}$ & Continues & $\begin{array}{l}\text { Turkish Statistic } \\
\text { Institution }\end{array}$ & $\begin{array}{l}\text { Monthly unemployment rate start- } \\
\text { ing with the first month }=1\end{array}$ & $\mathrm{C}_{2, \mathrm{~T}}$ \\
\hline $\begin{array}{l}\text { The Number of Surrenders } \\
\text { (SURREND) }\end{array}$ & $\mathrm{CV}$ & Count & $\begin{array}{l}\text { Turkish National } \\
\text { Police }\end{array}$ & $\begin{array}{l}\text { Aggregated number of those who } \\
\text { surrender voluntarily and leave } \\
\text { the PKK in each month }\end{array}$ & $\mathrm{C}_{4, \mathrm{~T}}$ \\
\hline $\begin{array}{l}\text { The Number of Operations (OP- } \\
\text { ERAT) }\end{array}$ & $\mathrm{CV}$ & Count & $\begin{array}{l}\text { Turkish National } \\
\text { Police }\end{array}$ & $\begin{array}{l}\text { Aggregated number of operations } \\
\text { initiated by the security forces } \\
\text { against the PKK in each month }\end{array}$ & $\mathrm{C}_{5, \mathrm{~T}}$ \\
\hline $\begin{array}{l}\text { The number of captured terror- } \\
\text { ists (CAPTURED) }\end{array}$ & $\mathrm{CV}$ & Count & $\begin{array}{l}\text { Turkish National } \\
\text { Police }\end{array}$ & $\begin{array}{l}\text { Aggregated number of captured } \\
\text { terrorists who were killed, wound- } \\
\text { ed, or alive) per month }\end{array}$ & $\mathrm{C}_{6, \mathrm{~T}}$ \\
\hline
\end{tabular}




\section{Data Analysis}

In the present study, the following models were developed to test the impact of governmental policy interventions on the number of incidents and causalities inflicted by the PKK. For general explanations, the terms $\varepsilon_{1, \mathrm{t}}$ and $\varepsilon_{2, \mathrm{t}}$ represent error terms and followed white noise processes with a zero mean and a constant variance $\left(0, \sigma^{2)} \cdot c_{i}^{\prime}\right.$ s represented the constant terms and $S_{k}$ represented seasonal dummies if these were statistically significant. While $\mathrm{Y}_{1, \mathrm{~T}}$ refers to the frequency of incidents committed by the PKK in the Model 1 (Incidents), $\mathrm{Y}_{2, \mathrm{~T}}$ refers to the frequency of casualties in the Model 2 (Casualties).

$$
\begin{aligned}
& Y_{1, T}=c_{1}+\sum_{k=1}^{12} S_{k}+\beta_{1} D_{1, T}+\beta_{2}\left(D_{2, T}+D_{3, T}+D_{4, T}\right)+\beta_{3} D_{2, T}+\beta_{4} D_{3, T}+\beta_{5} D_{4, T}+\sum_{j=1}^{7} \alpha_{1, T, j} C_{j, T}+\varepsilon_{1, T} \\
& Y_{2, T}=c_{2}+\sum_{k=1}^{12} S_{k}+\beta_{6} D_{1, T}+\beta_{7}\left(D_{2, T}+D_{3, T}+D_{4, T}\right)+\beta_{8} D_{2, T}+\beta_{9} D_{3, T}+\beta_{10} D_{4, T}+\sum_{j=1}^{7} \alpha_{2, T, j} C_{j, T}+\varepsilon_{2, T}
\end{aligned}
$$

The effect of $\mathrm{D}_{1, \mathrm{~T}}$ was measured separately, because this effect was not only about the PKK, but also about the whole country's situation. On the other hand; $\mathrm{D}_{2, \mathrm{~T}} \mathrm{D}_{3, \mathrm{~T}}$ and $\mathrm{D}_{4, \mathrm{~T}}$ interventions were used both aggregated and individually oriented.

\section{Findings}

The following table (Table 2) reveals the Negative Binominal results regarding the individual and aggregated impact of Turkish governmental interventions on the level of violent incidents inflicted by the PKK. 
Table 2: Negative Binomial Model Results for PKK initiated Incidents

\begin{tabular}{|c|c|c|c|c|}
\hline \multicolumn{5}{|c|}{ Dependent Variable: INC } \\
\hline \multicolumn{5}{|c|}{ Method: Maximum Likelihood - Negative Binomial Count Data Model } \\
\hline \multicolumn{5}{|c|}{ Included observations: 192} \\
\hline \multicolumn{5}{|c|}{ Huber/White robust standard errors \& covariance are used } \\
\hline Variable & Coefficient & Std. Error & z-Statistic & Prob. \\
\hline $\mathrm{C}$ & -2.65 & 1.10 & -2.42 & 0.02 \\
\hline @SEAS(1) & -0.91 & 0.43 & -2.11 & 0.04 \\
\hline$@ \operatorname{SEAS}(2)$ & -33.51 & 0.42 & -80.00 & 0.00 \\
\hline @SEAS(4) & -0.79 & 0.27 & -2.80 & 0.01 \\
\hline$@ \operatorname{SEAS}(7)$ & 0.57 & 0.32 & 1.79 & 0.07 \\
\hline @SEAS(12) & -0.91 & 0.34 & -2.62 & 0.01 \\
\hline D1 & -2.35 & 0.55 & -4.27 & 0.00 \\
\hline D2 & 0.30 & 0.75 & 0.39 & 0.69 \\
\hline D3 & 1.29 & 0.42 & 3.09 & 0.00 \\
\hline D4 & 0.33 & 0.55 & 0.60 & 0.55 \\
\hline $\mathrm{D} 2+\mathrm{D} 3+\mathrm{D} 4$ & 0.91 & 0.27 & 3.37 & 0.00 \\
\hline CAPTURED & -0.01 & 0.01 & -1.27 & 0.20 \\
\hline OPERAT & 0.04 & 0.02 & 2.57 & 0.81 \\
\hline SIZE & 0.01 & 0.00 & 3.11 & 0.00 \\
\hline SURREND & 0.00 & 0.01 & -0.11 & 0.92 \\
\hline UNEMP & -0.04 & 0.08 & -0.57 & 0.57 \\
\hline ACTION & 1.62 & 0.57 & 2.82 & 0.00 \\
\hline \multicolumn{2}{|c|}{ Akaike Info Criterion } & 2.55 & & \\
\hline \multicolumn{2}{|l|}{ Log Likelihood } & -234.04 & & \\
\hline \multicolumn{2}{|c|}{ Likelihood Ratio Statistic } & 91.88 & & \\
\hline \multicolumn{2}{|c|}{ Prob (LR Statistic) } & 0.00 & & \\
\hline
\end{tabular}

As plotted in Table 2, D3, the Active Repentance Law, which has been perceived as an amnesty, had a positive and statistically significant impact on the level of incidents carried out by the PKK at a $95 \%$ confidence level during its implementation period (2005-2010).

The effect of D2, the impact of the Returning Home Bill Policy, which was an amnesty targeting the PKK militants, and the effect of D4, the impact of the Democratic Initiative policy were found to be statistically insignificant even if the directions are in the anticipated way. Their $\mathrm{p}$ values are 0.69 and 0.55 respectively, which might be considered practical significant.

According to the table 2, Variable D1 has a negative and statistically significant effect on incidents at a $95 \%$ confidence level. This indicates that the accession process of Turkey to the European Union had a mitigating effect on the PKK initiated incidents.

Table 2 also reveals that incidents rarely occurred in the winters, while they mostly occurred in the summers.

The aggregated effect of governmental interventions $(\mathrm{D} 2+\mathrm{D} 3+\mathrm{D} 4)$ on the number of incidents initiated by the PKK was found to be positive and statistically significant at a 95\% confidence level. Considering the cumulative impact of these policies, this result clearly indicates that the defiance-based governmental interventions implemented by the Turkish state had an increasing effect rather than a decreasing or neutral 


\section{Journal of Terrorism Research}

effect on PKK-initiated incidents, contrary to the Turkish government`s expectations.

As related to the effects of the control variables on the number of incidents inflicted by the PKK, the effects of the capture of the PKK leader, and the aggregated number of estimated group sizes in each year were found to be statistically significant. These results reveal that capturing PKK leader had an increasing effect on the level of violent incidents, and as the group size of PKK increases, the number of incidents also increase.

The number of captured terrorists was found to have negative and significant effect on the number of PKK inflicted incidents, which means that the more the security forces capture PKK members, the less the number of incidents PKK initiated.

The Negative Binominal results regarding the individual and aggregated impact of Turkish governmental interventions on the level of casualties by the PKK are plotted in the following table (Table 3 ).

Table 3: Negative Binomial Model Results for PKK initiated Casualties

\begin{tabular}{|c|c|c|c|c|}
\hline \multicolumn{5}{|c|}{$\begin{array}{l}\text { Dependent Variable: CASUAL } \\
\text { Method: Maximum Likelihood - Negative Binomial Count Data Model } \\
\text { Included observations: } 192\end{array}$} \\
\hline Variable & Coefficient & Std. Error & z-Statistic & Prob. \\
\hline $\mathrm{C}$ & -1.76 & 1.38 & -1.28 & 0.20 \\
\hline$@ S E A S(2)$ & -125.23 & 0.44 & -284.61 & 0.00 \\
\hline @SEAS(4) & -0.9 & 0.37 & -2.43 & 0.01 \\
\hline @SEAS(7) & 1.57 & 0.52 & 3.02 & 0.00 \\
\hline @SEAS(12) & -1.08 & 0.5 & -2.16 & 0.03 \\
\hline D1 & -2.88 & 0.49 & -5.88 & 0.00 \\
\hline D2 & 0.06 & 0.09 & 0.67 & 0.56 \\
\hline D3 & 0.64 & 0.12 & 5.33 & 0.00 \\
\hline D4 & 0.32 & 0.13 & 2.46 & 0.01 \\
\hline $\mathrm{D} 2+\mathrm{D} 3+\mathrm{D} 4$ & 1.12 & 0.33 & 3.39 & 0.00 \\
\hline ACTION & 1.72 & 0.55 & 3.13 & 0.00 \\
\hline OPERAT & 0.032 & 0.02 & 1.40 & 0.19 \\
\hline CAPTURED & -0.019 & 0.017 & -1.14 & 0.55 \\
\hline UNEMP & -0.09 & 0.18 & -0.50 & 0.50 \\
\hline SIZE & 0.01 & 0.00 & 2.82 & 0.00 \\
\hline Akaike Info Criterion & \multicolumn{2}{|c|}{5.76} & & \\
\hline Log Likelihood & \multicolumn{2}{|c|}{-535.02} & & \\
\hline Likelihood Ratio Statistic & \multicolumn{2}{|c|}{370.81} & & \\
\hline Prob(LR Statistic) & \multicolumn{2}{|c|}{0.00} & & \\
\hline
\end{tabular}

Table 3 reveals that the Active Repentance Law (D3) and the Democratic Initiative Policy (D4) had a positive and statistically significant impact on the level of casualties initiated by the PKK.

The effects of the accession process of Turkey to the European Union on the number of casualties by PKK was found to be significant and in a negative direction. The accession process to the European Union (D1) had a negative and statistically significant effect on casualties at the 95\% confidence level. This shows had a significantly mitigating effect on casualties.

Although it was in the anticipated direction, the effect of the Returning Home Bill (D2) on the number of 


\section{Journal of Terrorism Research}

casualties inflicted by the PKK was found to be insignificant.

The aggregated impact of defiance-based governmental policies of Turkey (D2+D3+D4) was found to be positive and significant at the determined confidence level.

As related to the effects of the control variables on the number of casualties, table 3 reveals that the number of operations initiated by the security forces, the capture of the PKK leader, and the aggregated number of estimated group sizes in each year had an increasing and significant effect on casualties at a $95 \%$ confidence level.

Following Table (Table 4) reveals the hypothesis results of the study.

Table 4: Hypotheses Results

$\begin{array}{lll}\text { HYPOTHESES } & \text { RESULTS REMARKS }\end{array}$

H1: The defiance-based policies implemented by Turkey would increase the number of incidents inflicted by the PKK during the democratization period in Turkey.

D1: The Recognition of the Candidate Status of Turkey for Accession into the European Union (EU)

D2: The Returning Home Bill (July 2003-Jan 2004)

D3: The Active Repentance Law (Jun 2005 and after)

D4: The Democratic Initiative ("the Kurdish Opening") (Jul 2009 and after)

The Aggregated Impact of DR, D3, D4
NOT

SUPPORTED

NOT

SUPPORTED

$\mathrm{P}=0.69\left(\mathrm{P} \mathrm{S}^{*}\right)$

SUPPORTED

NOT

SUPPORTED

$\mathrm{P}=0.55(\mathrm{P} \mathrm{S})$

SUPPORTED
H2: The defiance-based policies implemented by Turkey would increase the number of casualties inflicted by the PKK during the democratization period in Turkey.

D1: The Recognition of the Candidate Status of Turkey for Accession into the European Union (EU)

D2: The Returning Home Bill (July 2003- Jan 2004)

D3: The Active Repentance Law (Jun 2005 and after)

D4: The Democratic Initiative ("the Kurdish Opening")

(Jul 2009 and after)

The Aggregated Impact of DR, D3, D4
NOT

SUPPORTED

$\begin{array}{ll}\text { NOT } & \mathrm{P}=0.56(\mathrm{P} \mathrm{S})\end{array}$

SUPPORTED

SUPPORTED

SUPPORTED

${ }^{\star}$ P S: Practical Significance

\section{Discussion and Conclusion}

In the present study, the impact of defiance/soft-line based Turkish governmental policies on the rates of terrorist attacks in the cases of the PKK over selected time period was evaluated. According to the Negative 


\section{Journal of Terrorism Research}

Binomial Models' estimation results, the study found that the soft-line policies enacted by the Turkish government had a significant and positive effect on the level of violence (incidents/casualties) inflicted by the PKK during the democratization process of Turkey. This finding was in contrast to the expectations of the Turkish governments.

The findings of the NB Models as regards casualties and incidents demonstrated that there was a positive and statistically significant relationship between the defiance based governmental policies and the level of violence initiated by the ethnically motivated terrorist groups. Even though the selected policy interventions were expected to reduce the level of violence (incidents and casualties), the increasing trend of both incidents and casualties as a response to those policies may be interpreted from four perspectives.

First, as discussed in the literature review section of this study, in order to capture the attention of society and seek more support, groups used terror as a tool. Thus, terrorist groups may respond to cultural and social reforms with increasing violence (Crenshaw 1995). Some terrorist groups, especially ethnically motivated groups, as observed this study, may perceive such policies as a sign of weakness, and a compromise on one of their demands, and may see it as a victory based on their increasing violence (Ünal 2011). In this sense, it may be said that one of the important reasons for increasing the level of violence by the PKK during the democratization period was to obtain more concessions from the Turkish government.

Second, the democratic initiatives and reforms toward removing ethnic grievances involved defiance and desistance based policy as mentioned in earlier. Therefore, their expected impact on the level violence may take longer than expected since they targeted grievances in the society to reduce their support for terrorist groups rather than targeting the militants. However, with respect to the NB estimation results, from the increasing trend of the level of violent incidents in response to such social policies it may be inferred that the PKK responded violently to the constitutional and democratic reforms to prevent their probable immediate impact on the Kurdish community by indicating that they were still powerful actors in solving the Kurdish problem.

Third, according to Crenshaw`s (1988) organizational approach, the targets of terrorism are symbolically related to the organization's ideological beliefs. Violence is thus the intentionally adopted choice of the terrorist group and explains the result of the organization`s struggle for survival. The organization 's leader offers many incentives to the followers to guarantee organizational maintenance (Crenshaw 1988). Therefore, some terrorist groups can obtain more benefits from illegal activities such as drug trafficking, weapon and human smuggling beside terrorism as mostly seen in the PKK case (Laciner 2008; Radu 2006; Sahin 2001; Steinberg 2008; Ward and Hill 2002). In addition, terrorist groups enjoy international and regional support (Martin 2012), which may make those groups key players in the country or region. Therefore, with respect to the NB estimation results, one of the reasons for the increasing level of violence during the intervention period may have been that the terrorist group, the PKK, was not willing to lose its gains obtained from their illegal activities and being seen as a regional actor.

Lastly, considering the targeted population of the amnesty policies (D2 and D3), the government targeted those militants who were not involved in any armed battle with the security forces or had not killed any citizen directly. Therefore, regarding the reasons for failure of these amnesty policies one may say that since the terrorist groups have a highly hierarchical structure, the counter strategies taken by the leadership cadre against these policies impaired the success of these laws. For this reason, the Active Repentance Bill (D3) of Turkey produced an increase of PKK initiated violence during the period when these policies were in force. Even though all the reasons mentioned above have attempted to explain why the PKK increased its attacks 


\section{Journal of Terrorism Research}

during democratization period, it should not be ignored that there is no one simple answer to explaining this process, and each alternative approach should be evaluated simultaneously with the other.

As mentioned earlier, fighting with ethnically-based terrorism is harder to quell than politically motivated terrorism because ethnically motivated terrorist groups have an opportunity to extract broader support from the population. Therefore, it is not as easy to stop or reduce this form of violence compared to other types of terrorism. It is really difficult to isolate regular civilians or sympathizers from the core violent group. Thus, countries struggling with ethnicity-based terrorism should focus more on its causes and employ soft-line policies to counter the grievances in a social context in order to arrive at a permanent solution. And these governmental policies must target the supporters or sympathizers of the terrorist group rather than focusing solely on incapacitating terrorists.

From the findings of this study, we suggest that since the PKK exploits democratic and social reforms such as constitutional and legal amendments, the "Kurdish Opening", the PKK violence has increased in order to eliminate the effectiveness of these reforms regarding Kurdish community. In contrast, the Kurdish people are pleased with those reforms and wants Turkey to take further actions. Therefore, even if PKK violence increases to sabotage the current process, Turkey's democratization process should not be terminated.

Eventually, many ethnic conflicts in the world demonstrate that a resolution for solving these problems may be possible as in the examples of countries such as Spain, the UK, and Belgium which have well-established democracies rather than antidemocratic countries or less functional democracies such as the Sudan, Iraq, India, Georgia, and China. Thus, countries should continue to consolidate their process towards democracy in order to provide a permanent solution for solving their ongoing ethnic conflicts despite the fact that the violent groups may increase their attacks against the state and civilians. While the country is fighting terrorist groups within its territory on one hand, it should not neglect to implement democratic reforms meeting all citizens' democratic demands, on the other. The states thus may solve their protracted ethnic conflicts in the long run. Therefore, the Turkish state should also continue its democratic reforms regardless of the methods used by the PKK.

\section{About the authors:}

Irfan Ciftci, PhD, is a police major of Turkish National Police. He received his PhD from the Global Affairs, Rutgers State University. His research interests are terrorism, political violence, globalization, international cooperation, and law enforcement training.

Sedat Kula, PhD, is a police major of Turkish National Police. He received his PhD from the Public Administration Department of the College of Health and Public Affairs, University of Central Florida. His researches focus on law enforcement, occupational stress in public sector, social capital, structural equation modeling (SEM), and law enforcement training.

\section{Notes}

[1] Kurdish conflict is also known as Kurdish Issue or Kurdish Question; therefore these terms will be used interchangeable throughout the study. 


\section{The Centre for the Study of Terrorism and Political Violence \\ Journal of Terrorism Research}

\section{References}

Ankara Papers. 2004. “The Case of the PKK: History, Ideology, Methodology, and Structure (1978-99).” Ankara Papers 9 (1): 21-59.

Balci, Fatih. 2008. Politicization of Kurdish Question through Human Rights Discourse in Turkey. ProQuest.

Barkey, H.J. 2009. “Will Turkey’s 'Kurdish Initiative’ succeed?” http://carnegieendowment.org/2009/08/13/will-turkey-s-kurdish-initiative-succeed/9ke.

Barros, C.P., J. Passos, and L.A. Gil-Alana. 2006. “The Timing of ETA Terrorist Attacks.” Journal of Policy Modeling 28 (3): 335-46.

Barros, Carlos Pestana. 2003. "An Intervention Analysis of Terrorism: The Spanish Eta Case." Defence and Peace Economics 14 (6): 401-12. doi:10.1080/1024269032 000085170 .

Birch, Nicholas. 2009. “Turkey Seeks End to Kurdish Conflict." http://online.wsj.com/article/SB124950871809009061.html.

Button, S.H. 1995. “Turkey Struggles with Kurdish Separatism.” Military Review 75: 70-70.

Byman, D. 1998. “The Logic of Ethnic Terrorism.” Studies in Conflict \& Terrorism 21 (2): 149-69.

Cakar, Bekir, Mahmut Cengiz, and Fatih Tombul. 2011. "The History of The PKK.” In The PKK: Financial Sources, Social and Political Dimensions. Columbia University Press.

Çandar, Cengiz. 2011. “Dağdan İniş-PKK Nasıl Silah Bırakır?” http://www.tesev.org.tr/Upload/Publication/674c1f00-fc7f-4f91-b2e4-2ef8d91f1815/11452\%20 SilahsizlandirmaWEB.pdf.

Çarkoğlu, Ali, and Barry M. Rubin. 2003. Turkey and the European Union: Domestic Politics, Economic Integration, and International Dynamics. Psychology Press. Cauley, Jon, and Eric Iksoon Im. 1988. “Intervention Policy Analysis of Skyjackings and Other Terrorist Incidents.” The American Economic Review 78 (2): 27-31. Crenshaw, M. 1988. “Theories of Terrorism: Instrumental and Organizational Approaches (From Inside Terrorist Organizations, P 13-31, 1988, David C Rapoport, Ed. - See NCJ-111830)." https://www.ncjrs.gov/App/publications/Abstract.aspx?id=111831.

- - . 1995. Terrorism in Context. Penn State University Press 1999. "How Terrorism Ends". US Institute of Peace working group report. http://dspace. cigilibrary.org/jspui/bitstream/123456789/4520/1/How\%20Terrorism\%20Ends.pdf?1.

Dugan, Laura, Gary Lafree, and Alex R. Piquero. 2005. “Testing a Rational Choice Model of Airline Hijackings*”. Criminology 43 (4): 1031-65. doi:10.1111/j.17459125.2005.00032.x.

Enders, Walter, and Todd Sandler. 1993. “The Effectiveness of Antiterrorism Policies: A Vector-Autoregression- Intervention Analysis." The American Political Science Review 87 (4): 829-44. doi:10.2307/2938817.

_- - 2000. “Is Transnational Terrorism Becoming More Threatening? A Time-Series Investigation.” The Journal of Conflict Resolution 44 (3): $307-32$.

Entessar, Nader. 2009. Kurdish Politics in the Middle East. Lexington Books.

Ergil, Dogu. 2000. “The Kurdish Question in Turkey.” Journal of Democracy 11 (3): 122-35. doi:10.1353/jod.2000.0054.

Eser, Tarik. 2007. The Role of Turkish State towards the PKK:Time Series Analysis. Sam Huston State University: PhD Thesis.

Feridun, M., and M. Shahbaz. 2010. "Fighting Terrorism: Are Military Measures Effective? Empirical Evidence from Turkey." Defence and Peace Economics 21 (2): 193-205.

Hannum, H. 1996. Autonomy, Sovereignty, and Self-Determination: The Accommodation of Conflicting Rights. Univ of Pennsylvania Pr.

Hewitt, C. 1984. The Effectiveness of Anti-Terrorist Policies. University Press of America Lanham, MD. http://www.ncjrs.gov/App/abstractdb/AbstractDBDetails. aspx?id=96049.

Jwaideh, W. 2006. The Kurdish National Movement: Its Origins and Development. Syracuse Univ Pr.

Keyman, Emin Fuat. 2007. Remaking Turkey: Globalization, Alternative Modernities, and Democracy. Lexington Books.

Kim, E., and M. Yun. 2008. "What Works? Countermeasures to Terrorism: A Case Study of PKK." International Journal of Comparative and Applied Criminal Justice 


\section{The Centre for the Study of Terrorism and Political Violence \\ Journal of Terrorism Research}

$32(1): 65-88$

Kirişçi, K., and G.M. Winrow. 1997. The Kurdish Question and Turkey: An Example of a Trans-State Ethnic Conflict. Routledge.

Kutschera, Chris. 1999. “The 'Middle East' Talks to Abdullah Ocalan.” http://findarticles.com/p/articles/mi_m2742/is_289/ai_n25026117/.

Laciner, Sedat. 2008. “Drug Smuggling As Main Source of PKK Terrorism.” http://www.turkishweekly.net/columnist/2994/drug-smuggling-as-main-source-of-pkkterrorism.html.

Landes, William M. 1978. “Economic Study of U.S. Aircraft Hijacking, 1961-1976, An.” Journal of Law \& Economics 21 : 1.

Lum, Cynthia, Leslie Kennedy, and Alison Sherley. 2006. "Are Counter-Terrorism Strategies Effective? The Results of the Campbell Systematic Review on CounterTerrorism Evaluation Research." Journal of Experimental Criminology 2 (4): 489-516. doi:10.1007/s11292-006-9020-y.

Martin, C. G. A. 2012. Understanding Terrorism: Challenges, Perspectives, and Issues. Sage Publications, Incorporated.

Mead, Walter Russell. 2005. Power, Terror, Peace, and War: America's Grand Strategy in a World at Risk. Vintage.

Netanyahu, B. 1995. Fighting Terrorism: How Democracies Can Defeat Domestic and International Terrorists. Farrar Straus \& Giroux.

Radu, Michael. 2006. Dilemmas of Democracy \& Dictatorship: Place, Time, and Ideology in Global Perspective. Transaction Publishers.

Roth, M.P., and M. Sever. 2007. “The Kurdish Workers Party (PKK) as Criminal Syndicate: Funding Terrorism through Organized Crime, a Case Study." Studies in Conflict and Terrorism 30 (10): 901-20.

Sahin, Fuat Salih. 2001. "Case Studies in Terrorism-Drug connection:The Kurdistan Workers' Party,The Liberatıon Tigers of Tamil Eelam, and the Shining Path". Texas: University Of North Texas. http://digital.library.unt.edu/ark:/67531/metadc2871/m2/1/high_res_d/thesis.pdf.

Sherman, L. W. 1993. “Defiance, Deterrence, and Irrelevance: A Theory of the Criminal Sanction.” Journal of Research in Crime and Delinquency 30 (4): 445-73. Steinberg, Michele. 2008. “PKK Terrorists Named 'Drug Kingpins’; Nations Move against Narcoterrorism” 35. http://larouchepub.com/other/2008/3530pkk_ terrorists.html.

Teymur, S., and C. J. Smith. 2008. The PKK: A Decades-Old Brutal Marxist-Leninist Separatist Terrorist Organization. Washington: Turkish Institute for Security and Democracy.

Unal, Mustafa Cosar. 2009. “Turkish Responses to Violence by the Kurdistan Workers’ Party (PKK): Policy Choices and Policy Effects”. Baltimure County: University of Maryland.

Ünal, Mustafa Cosar. 2011. Counterterrorism in Turkey: Policy Choices and Policy Effects toward the Kurdistan Workers Party (Pkk). Taylor \& Francis Group.

Ward, Richard H., and Sean David Hill. 2002. Extremist Groups: An International Compilation of Terrorist Organizations, Violent Political Groups, and Issue-Oriented Militant Movements. Office of International Criminal Justice.

Wilkinson, P. 2011. Terrorism versus Democracy. Routledge. 